\title{
PENGARUH KECERDASAN INTELEKTUAL DAN KECERDASAN EMOSIONAL TERHADAP PRESTASI AKADEMIK MAHASISWA MANAJEMEN FAKULTAS EKONOMI UNIVERSITAS TADULAKO
}

\author{
KHUSNUL HATIMA \\ NILUH PUTU EVVY ROSSANTY \\ RISNAWATI \\ Jurusan Manajemen, Fakultas Ekonomi, Universitas Tadulako \\ E-mail: khusnulhatima01@gmail.com
}

\begin{abstract}
This study determines simultaneous and partial influence of intellectual intelligence and emotional intelligence on academic achievement of Management Department Students of 2013 and 2014 at the Faculty of Economics, Tadulako University. The type of research is quantitative and sampling technique applies purposive sampling, with a total sample of 83 respondents consisting of 36 students of class 2013 and 47 students of class of 2014. Data collection methods include observation, interviews, and questionnaires. The results of this study show that the variables intelligence (XI) and emotional intelligence (X2) simultaneously influence academic achievement $(Y)$ with sig. value of $0.000<0.05$. Furthermore, variable intellectual intelligence $(X 1)$ with sig. value of 0.003 , and Emotional Intelligence (X2) with sig is 0,001 that showing partial influences on academic achievement $(Y)$.
\end{abstract}

Keywords: intellectual intelligence, emotional intelligence, academic achievement.

\section{Abstrak}

Penelitian ini bertujuan untuk mengetahui pengaruh secara simultan dan parsial dari kecerdasan intelektual dan kecerdasan emosional terhadap prestasi akademik Mahasiswa Manajemen Angkatan 2013 dan 2014 Fakultas Ekonomi Universitas Tadulako. Jenis penelitian yang digunakan adalah kuantitatif dan teknik penarikan sampel dalam penelitian ini adalah purposive sampling, dengan jumlah sampel sebanyak 83 responden yang terdiri dari 36 mahasiswa angkatan 2013 dan 47 mahasiswa angkatan 2014. Pengambilan data menggunakan metode observasi, wawancara, dan kuesioner. Hasil Penelitian ini menunjukkan bahwa variabel kecerdasan intelektual (X1) dan kecerdasan emosional (X2) terhadap prestasi akademik (Y) berpengaruh secara simultan dengan nilai sig sebesar $0,000<0,05$. Selanjutnya variabel Kecerdasan Intelektual (X1) dengan nilai sig sebesar 0,003, dan Kecerdasan Emosional (X2) dengan nilai sig sebesar 0,001 yang berarti secara parsial berpengaruh terhadap Prestasi Akademik (Y).

Kata Kunci: Kecerdasan Intelektual, Kecerdasan Emosional,Prestasi Akademik.

\section{PENDAHULUAN}

Pendidikan merupakan suatu usaha atau kegiatan yang dijalankan dengan sengaja, teratur dan berencana dengan maksud mengubah atau mengembangkan perilaku yang diinginkan. Pendidikan tinggi sebagai lembaga yang membekali peserta didik dengan penekanan pada nalar dan pemahaman pengetahuan berdasarkan keterkaitan teori dan mengaplikasikannya dalam dunia praktek. Universitas sebagai lembaga formal, dalam hal ini Universitas Tadulako Jurusan Manajemen Fakultas Ekonomi merupakan sarana dalam rangka pencapaian tujuan pendidikan tersebut. Melalui pendidikan seseorang dapat meraih tujuan dan cita-citanya.

Pada pendidikan formal, belajar menunjukkan adanya perubahan yang sifatnya positif sehingga pada tahap akhir akan didapat keterampilan, kecakapan dan pengetahuan baru. Hasil dari proses belajar tersebut tercermin dalam prestasi belajarnya. Namun dalam upaya meraih prestasi belajar yang memuaskan dibutuhkan proses belajar. Untuk meraih prestasi yang tinggi dalam belajar, seseorang harus memiliki Intelligence Quotient (IQ) yang tinggi, karena inteligensi merupakan bekal potensial yang akan memudahkan dalam belajar dan pada gilirannya akan menghasilkan prestasi belajar yang optimal. Hal ini mendasar pemikiran akan perlunya dalam meningkatkan kecerdasan intelektual. 
Intelegensi dapat diartikan sebagai kemampuan untuk memahami dan menyelesaikan masalah. Menurut Kartono (1995:1) Kecerdasan intelektual merupakan "Salah satu aspek yang penting dan sangat menentukan berhasil atau tidaknya studi seseorang. Apabila seorang siswa mempunyai kecerdasan normal atau diatas normal maka dalam potensial ia dapat berprestasi tinggi". Slameto (1995:56) Mengatakan bahwa " Tingkat intelegensi yang tinggi akan lebih berhasil dari pada yang memiliki intelegensi yang rendah". Dalam pra penelitian,yang dilakukan peneliti di Fakultas Ekonomi Jurusan Manajemen Universitas Tadulako dengan beberapa orang mahasiswa angkatan 2013 dan 2014 melalui wawancara, yang menjadi masalah yaitu ada mahasiswa yang menyatakan bahwa ada mahasiswa angkatan 2013 dan 2014 yang memiliki kecerdasan intelektual yang tinggi tetapi memiliki kecerdasan emosional yang rendah sehingga memperoleh prestasi belajar yang rendah. Itu sebabnya kecerdasan intelektual bukan merupakan satu-satunya faktor yang menentukan keberhasilan seseorang, karena ada faktor lain yang mempengaruhi, faktor tersebut antara lain adalah kecerdasan emosional, kondisi sosial ekonomi mahasiswa yang bersangkutan, minat dan kemauan belajar mahasiswa, serta masih banyak faktor lainnya,Joseph (1998:8). Namun dalam penelitian ini penulis memilih dua faktor yaitu kecerdasan intelektual dan kecerdasan emosional Mahasiswa Jurusan Manajemen Fakultas Ekonomi Universitas Tadulako.

Berdasarkan uraian di atas, peneliti tertarik untuk melakukan penelitian tentang pengaruh kecerdasan intelektual dan kecerdasan emosional, dalam hal ini yang menjadi subjek adalah mahasiswa jurusan manajemen angkatan 2013 dan 2014 Fakultas Ekonomi Universitas Tadulako. Topik yang akan diteliti berjudul "Pengaruh Kecerdasan Intelektual dan Kecerdasan Emosional terhadap Prestasi Akademik Mahasiswa Manajemen" khususnya pada Jurusan Manajemen Angkatan 2013 dan 2014 Fakultas Ekonomi Universitas Tadulako dengan tujuan

1. Untuk mengetahui pengaruh secara simultan dari variabel Kecerdasan Intelektual dan kecerdasan Emosional terhadap Prestasi Akademik mahasiswa jurusan manajemen Fakultas Ekonomi Universitas Tadulako.

2. Untuk mengetahui dan menganalisis pengaruh secara parsial variabel Kecerdasan Intelektual terhadap Prestasi Akademik mahasiswa jurusan manajemen Fakultas Ekonomi Universitas Tadulako.

3. Untuk mengetahui dan menganalisis pengaruh secara parsial variabel Kecerdasan Emosional terhadap Prestasi Akademik mahasiswa jurusan manajemen Fakultas Ekonomi Universitas Tadulako.

4. Untuk mengetahui dan menganalisis antara Variabel Kecerdasan Intelektual dan Kecerdasan Emosional manakah yang berpengaruh paling dominan terhadap prestasi akademik mahasiswa jurusan manajemen Fakultas Ekonomi Universitas Tadulako.

5. Untuk mengetahui dan menganalisis antara variabel kecerdasan intelektual dan kecerdasan emosional manakah yang berpengaruh paling dominan terhadap prestasi akademik mahasiswa manajemen faakultas ekonomi universitas tadulako.

\section{KAJIAN LITERATUR DAN PENGEMBANGAN HIPOTESIS Pengertian Kecerdasan Intelektual}

Kecerdasan intelektual adalah kesanggupan untuk menyesuaikan diri kepada kebutuhan baru dengan menggunakan alat-alat berfikir yang sesuai dengan tujuan.

\section{Dimensi Kecerdasan Intelektual}

Dalam penelitian ini kecerdasan intelektual mahasiswa di ukur dengan dimensi sebagai berikut: (Stenberg, 1981) dalam Dwijayanti (2009)

1. Kemampuan Memecahkan Masalah

Kemampuan memecahkan masalah yaitu mampu menunjukkan pengetahuan mengenai masalah yang dihadapi, mengambil keputusan tepat, menyelesaikan masalah secara optimal, menunjukkan fikiran jernih.

2. Intelegensi Verbal

Intelegensiverbal yaitu kosa kata baik, membaca dengan penuh pemahaman, ingin tahu secara intelektual, menunjukkan keingintahuan. 
3. Intelegensi Praktis

Intelegensi praktis yaitu tahu situasi, tahu cara mencapai tujuan, sadar terhadap dunia keliling, menujukkan minat terhadap dunia luar.

\section{Pengertian Kecerdasan Emosional}

Kecerdasan Emosional merupakan suatu sikap dasar yang dimiliki individu dalam merasakan, memahami perasaan dri sendiri maupun orang lain.

\section{Dimensi Kecerdasan Emosional}

Goleman (2007:58-59) memaparkan bahwa kecerdasan emosional (EQ) mempunyai lima komponen atau dimensi, dan tiap komponen mempunyai beberapa Pengembangan SDM. Kelima komponen/dimensi di atas adalah sebagai berikut:

1. Pengenalan Diri (self-awareness)

Pengenalan diri merupakan dasar dari kecerdasan emosional, pengenalan diri adalah kemampuan untuk mengenali perasaan sendiri dan mengatur perasaan tersebut dalam cara yang dapat dikontrol, memandu pemecahan masalah, memiliki tolak ukur yang realistis atas kemampuan diri dan kepercayaan diri yang kuat.

2. Pengendalian diri ( self-regulation)

Pengendalian diri adalah kemampuan untuk mengelola emosi sehingga emosi dapat diungkap dengan tepat, kemampuan untuk menenangkan diri dari kecemasan, kemurungan dari kemarahan yang menjadi serta mampu pulih dari tekanan emosi.

3. Motivasi (motivation)

Motivasi adalah sesuatu yang menggunakan hasrat individu yang paling dalam untuk menggerakan dan menuntun menuju sasaran, membantu mengambil inisiatif dan bertindak sangat efektif, serta untuk bertahan menghadapi kegaagalan.

4. Empati (empathy)

Empati adalah kemampuan mengetahui perasaan orang lain, menyesuaikan diri terhadap apa yang diinginkan orang lain, menumbuhkan hubungan saling percaya dan menyelaraskan diri dengan bermacam-macam orang.

5. Keterampilan sosial (social skills)

Keterampilan sosial adalah kemahiran dalam mengubah tanggapan yang dikehendaki oleh orang lain. Diantaranya adalah kemampuan persuasi, mendengar dengan terbuka dan memberi pesan yang jelas, kemampuan menyelesaikan pendapat.

\section{Prestasi Akademik}

Secara lebih khusus prestasi akademik dapat diartikan sebagai suatu bukti keberhasilan belajar dalam bidang akademik atau kemampuan seseorang siswa dalam melakukan kegiatan belajarnya dalam bidang akademik sesuai dengan bobot yang dicapainya. Prestasi menurut Benyamin S.Bloom (1956) itu meliputi 3 (tiga) dimensi, yaitu:

\section{Ranah Kognitif}

Pada dasarnya Kognitif adalah kemampuan siswa dalam berpikir. Ranah kognitif berhubungan dengan kemampuan berfikir, termasuk didalamnya kemampuan menghafal, memahami, dan penerapan.

2. Ranah Afektif

Ranah afektif adalah ranah yang berkaitan dengan sikap dan nilai. Ranah afektif mencakup watak perilaku seperti perasaan, minat, sikap, emosi, dan nilai.

3. Ranah Psikomotor

Ranah psikomotor adalah kemampuan yang dihasilkan oleh fungsi motorik manusia yaitu berupa keterampilan untuk melakukan sesuatu.

\section{Kerangka Pemikiran}

Dalam memperoleh prestasi akademik yang baik maka diperlukan kecerdasan intelektual. Hal ini karena intelegensi merupakan bekal potensial yang akan menetapkan suatu tujuan, begitu pula dengan Kecerdasan emosional yang merupakan kemampuan lebih yang dimiliki seseorang dalam 
memotivasi diri, ketahanan dalam menghadapi kegagalan, mengendalikan emosi dan menunda kepuasan, serta mengatur keadaan jiwa (Goleman, 2003).

Kecerdasan emosional mahasiswa memiliki pengaruh terhadap prestasi belajar mahasiswa. Kecerdasan emosional ini mampu melatih kemampuan untuk mengelola perasaannya, kemampuan untuk memotivasi dirinya, kesanggupan untuk tegar dalam menghadapi frustasi, kesanggupan mengendalikan dorongan dan menunda kepuasan sesaat, mengatur suasana hati yang reaktif, serta mampu berempati dan bekerja sama dengan orang lain. Dalam proses belajar mahasiswa untuk meraih prestasi akademik yang baik maka diperlukan kemampuan intelektual dan kecerdasan emosional yang saling berinteraksi. Kerangka pemikiran dibuat untuk menggambarkan keterkaitan dari variabelvariabel yang akan diteliti, dalam hal ini Kecerdasan Intelektual dan Kecerdasan Emosional sebagai Variabel X dan Prestasi Akademik sebagai Variabel Y. Untuk lebih jelasnya dapat dilihat pada gambar berikut:

\begin{tabular}{|c|c|}
\hline Kecerdasan Intelektual (X1) & \\
\hline \multirow{3}{*}{$\begin{array}{l}\text { 1. Kemampuan memecahkan masalah } \\
\text { 2. Intelegensi verbal } \\
\text { 3. Intelegensi praktis } \\
\text { (Sumber:Stenberg, } 1981 \text { dalam Dwijayanti 2009) }\end{array}$} & \\
\hline & Prestasi Akademik (Y) \\
\hline & $\begin{array}{l}\text { 1. Ranah kognitif } \\
\text { 2. Ranah afektif }\end{array}$ \\
\hline Kecerdasan Emosional (X2) & 3. Ranah psikomotor \\
\hline $\begin{array}{l}\text { 1. Pengenalan diri (Sumber: Benjamin S. } \\
\text { 2. Pengendalian diri } \\
\text { 3. Motivasi } \\
\text { 4. Empati }\end{array}$ & Bloom,1956) \\
\hline $\begin{array}{c}\text { 5. Keterampilan sosial } \\
\text { (Sumber:Goleman (2007:58-59) }\end{array}$ & \\
\hline
\end{tabular}

Gambar 1 Kerangka Pemikiran Penelitian

\section{Hipotesis}

Berdasarkan rumusan masalah dan kajian pustaka yang akan dikemukakan maka dapat disusun hipotesis penelitian sebagai berikut :

1. Kecerdasan Intelektual berpengaruh secara simultan terhadap Prestasi Akademik mahasiswa Jurusan Manajemen Universitas Tadulako.

2. Kecerdasan Emosional berpengaruh secara simultan terhadap Prestasi Akademik mahasiswa Jurusan Manajemen Universitas Tadulako.

3. Kecerdasan Intelektual yang terdiri dari Kemampuan memecahkan masalah, intelegensi verbal dan intelegensi praktis berpengaruh secara parsial terhadap Prestasi Akademik mahasiswa Jurusan Manajemen Universitas Tadulako.

4. Kecerdasan Emosional yang terdiri dari pengenalan diri, pengendalian diri, motivasi, empati, dan keterampilan sosial secara parsial berpengaruh positif dan signifikan terhadap Prestasi Akademik mahasiswa Jurusan Manajemen Universitas Tadulako.

\section{Metode Penelitian}

Menurut Kuncoro (2009:118), populasi adalah kelompok elemen yang lengkap, yang biasanya berupa orang, objek, transaksi, atau kejadian dimana kita tertarik untuk mempelajarinya atau menjadi objek penelitian.Populasi dalam penelitian ini adalah Mahasiswa Jurusan Manajemen Angkatan 2013 dan 2014 karena angkatan tersebut merupakan mahasiswa yang aktif dalam perkuliahan. 
Tabel 1 Daftar Populasi Penelitian Jurusan Manajemen

\begin{tabular}{|c|c|c|}
\hline No & Angkatan & Jumlah \\
\hline 1 & 2013 & 214 orang \\
\hline 2 & 2014 & 280 orang \\
\hline & Total & 494 orang \\
\hline
\end{tabular}

Sumber: UPT Komputer Fakultas Ekonomi Universitas Tadulako (2016)

Sampel adalah bagian dari jumlah dan karateristik yang dimiliki oleh populasi tersebut Sugiyono (2009:116). Apabila jumlah populasi besar maka perlu melakukan penarikan sampel. Penggunaan sampel ini bertujuan untuk memperoleh keterangan-keterangan mengenai populasi dari mana sampel tersebut dipilih karena jumlah populasi yang besar. Menurut Umar (2008) bahwa untuk menentukan jumlah minimal sampel yang dibutuhkan untuk ukuran populasi, dapat diketahui dengan menggunakan rumus Slovin, yaitu sebagai berikut :

$$
\mathrm{n}=\frac{\mathrm{N}}{{ }^{1}+\mathrm{N}(\mathrm{e})^{2}}
$$

Sehingga dapat diperoleh jumlah sampel dalam penelitian ini adalah:

$$
\mathrm{n}=\frac{494}{1+494(0,1)^{2} \mathrm{n}}=83,16 \text { sampel, dibulatkan menjadi } 83
$$

sampel.

Berdasarkan perhitungan diatas, maka di peroleh sampel penelitian sebanyak 83 sampel. Jadi jumlah sampel dalam penelitian ini adalah 83 Mahasiswa.Jumlah anggota sampel bertingkat (berstrata) dilakukan dengan teknik proportional stratified random sampling.

Jumlah anggota sampel teknik proportional stratified random sampling berdasarkan Angkatan 2013 dan 2014 adalah:

Angkatan 2013: $214 / 494=0.43 \times 83$ orang $=36$ orang

Angkatan 2014: $280 / 494=0.57$ x 83 orang $=47$ orang

\section{HASIL DAN PEMBAHASAN}

\begin{tabular}{|c|c|c|c|c|c|c|}
\hline \multirow[t]{2}{*}{ Variabel } & \multicolumn{2}{|c|}{$\begin{array}{l}\text { Unstandardized } \\
\text { Coefficients (B) }\end{array}$} & \multirow{2}{*}{\multicolumn{2}{|c|}{$\begin{array}{l}\text { Standardized } \\
\text { Coefficients } \\
\text { Beta }\end{array}$}} & \multirow[t]{2}{*}{$\mathrm{T}$} & \multirow[t]{2}{*}{ Sig. } \\
\hline & B & Std. Error & & & & \\
\hline (Constant) & .983 & .540 & & & 1.819 & .073 \\
\hline Kecerdasan Intelektual $\left(\mathrm{X}_{1}\right)$ & .318 & .103 & .317 & & 3.091 & .003 \\
\hline Kecerdasan Emosional $\left(\mathrm{X}_{2}\right)$ & .463 & .137 & .347 & & 3.378 & .001 \\
\hline R Square $\left(\mathrm{R}^{2}\right)$ & $=0.318$ & F- hitung & & $=18.61$ & & \\
\hline Adjusted R Square & $=0.301$ & Constanta & & $=0.983$ & & \\
\hline Multiple R & $=0.564$ & Sig. F & & $=0.000$ & & \\
\hline Jumlah data 83 Responden & & & & & & \\
\hline
\end{tabular}

Tabel 2 Hasil Perhitungan Regresi Linear Berganda

Sumber: Data Diolah Kembali, 2016 
Berdasarkan uraian Tabel 2 tentang hasil perhitungan regresi linear berganda, maka persamaan regresi yang dibangun dengan menggunakan nilai-nilai yang diperlukan sebagai berikut:

$$
\mathrm{Y}=\mathbf{0 , 9 8 3}+\mathbf{0 , 3 1 8}\left(\mathrm{X}_{1}\right)+\mathbf{0 , 4 6 3}\left(\mathrm{X}_{2}\right)
$$

Berdasarkan persamaan tersebut maka dapat dinyatakan variabel independen atau variabel bebas. Penjelasan nilai koefisien dapat diuraikan sebagai berikut:

a. Nilai konstanta (a) adalah 0,983, artinya apabila variabel kecerdasan intelektual (X1) dan kecerdasan emosional (X2) nilainya 0, maka prestasi akademik mahasiswa Manajemen Fakultas Ekonomi Universitas Tadulako tetap positif 0,983.

b. Nilai koefisien regresi variabel kecerdasan intelektual (X1) bernilai positif yaitu 0,318. Hal ini menyatakan bahwa nilai kecerdasan intelektual meningkat maka akan meningkatkan prestasi akademik mahasiswa Manajemen Fakultas Ekonomi Universitas Tadulako.

c. Nilai koefisien regresi variabel kecerdasan emosional (X2) bernilai positif yaitu 0,463. Hal ini menyatakan bahwa nilai kecerdasan emosional meningkat maka akan meningkatkan prestasi akademik mahasiswa Manajemen Fakultas Ekonomi Universitas Tadulako.

\section{Pengujian Hipotesis Pertama Secara Simultan (Serempak/Uji F)}

Berdasarkan hasil uji regresi pada tabel di atas, diperoleh $F_{\text {hitung }}$ sebesar 18.617 dengan tingkat signifikansi $0,000<0,05$, yang dapat diartikan bahwa variabel Kecerdasan Intelektual (X1) dan variabel Kecerdasan Emosional (X2) yang dimasukkan dalam model, secara serempak berpengaruh signifikan terhadap variabel Prestasi Akademik (Y). berdasarkan hasil tersebut dapat disimpulkan bahwa $\mathrm{H}_{0}$ ditolak dan $\mathrm{H}_{1}$ diterima, atau bila dijabarkan secara mendasar bahwa dalam penelitian ini hipotesis yang pertama terbukti sebagai suatu kebenaran empiris (nyata) setelah diuji dengan hasil penelitian.

\section{Pengujian Hipotesis Kedua(Uji Parsial/Uji t)}

Pengujian terhadap pengaruh masing-masing variabel independen terhadap variabel dependen disebut uji parsial. Uji parsial pada fungsi estimasi bertujuan untuk membuat kesimpulan mengenai pengaruh masing-masing variabel independen $(\mathrm{X})$ terhadap variabel dependen $(\mathrm{Y})$. Uji t dilakukan dengan membandingkan nilai t sig. dengan nilai $\alpha$. Jika probabilitas $t$ sig. $<\alpha(0,05)$ maka terdapat pengaruh signifikan, sebaliknya jika nilai t sig. $>\alpha(0,05)$ maka tidak terdapat pengaruh signifikan. Berdasarkan hasil pengujian yang diperoleh dalam penelitian, dapat dijelaskan hasil uji $t$ dari variabel independen adalah sebagai berikut:

a. Kecerdasan Intelektual (X1)〉

Variabel kecerdasan emosional memiliki tingkat signifikansi t sig. $(0,003)<\alpha(0,05)$. Hal ini menunjukkan bahwa hipotesis yang menyatakan "Kecerdasan emosional secara parsial berpengaruh signifikan terhadap Prestasi Akademik Mahasiswa Manajemen Fakultas Ekonomi Universitas Tadulako" terbukti atau hipotesis tersebut diterima.

b. Kecerdasan Emosional (X2) Variabel Kecerdasan Emosional memiliki tingkat signifikansi probabilitas $t$ sig. $(0.001)<\alpha(0,05)$. Hal ini menunjukkan bahwa hipotesis yang menyatakan bahwa "Kecerdasan Emosional berpengaruh signifikan terhadap Prestasi Akademik Mahasiswa Manajemen Fakultas Ekonomi Universitas Tadulako" terbukti atau hipotesis tersebut diterima.

\section{Pembahasan Hasil Penelitian \\ Pengaruh Kecerdasan Intelektual Terhadap Prestasi Akademik Mahasiswa Manajemen Universitas Tadulako}

Inteligensi merupakan bekal potensial yang akan memudahkan dalam belajar dan pada gilirannya akan menghasilkan prestasi belajar yang optimal. Berdasarkan hasil penelitian telah terbukti bahwa kecerdasan intelektual berpengaruh secara simultan terhadap Prestasi AkademikMahasiswa Manajemen Fakultas Ekonomi Universitas Taduako, karena hasil pengujian menunjukkan bahwa variabel kecerdasan intelektual memberikan pengaruh positif terhadap prestasi akademik. Hal ini sejalan dengan peneliti sebelumnya Febri Sulistiya (2012) Bahwa Kecerdasan Intelektual berpengaruh signifikan terhadap prestasi belajar Siswa di Yogyakarta.Hasil Penelitian ini sesuai dengan yang dikemukakan Kartono (1995:1) Kecerdasanintelektualmerupakan salah satu aspek yang penting dan sangat menentukan berhasil atau tidaknya studi seseorang. 
Kecerdasan Intelektual juga berpengaruh secara parsial terhadap Prestasi Akademik Mahasiswa Manajemen Fakultas Ekonomi Universitas Tadulako. Adapun dimensi dari kecerdasan intelektual yaitu kemampuan memecahkan masalah, intelegensi verbal, dan intelegensi praktis dan yang mempunyai mean tertinggi yaitu kemampuan memecahkan masalah, artinya yaitu kemampuan memecahkan masalah Mahasiswa Manajemen angkatan 2013 dan 2014 Fakultas Ekonomi Universitas Tadulako sangat baik, dan merupakan salah satu faktor yang penting untuk meningkatkan prestasi akademik mahasiswa.

\section{Pengaruh Kecerdasan Emosional Terhadap Prestasi Akademik Mahasiswa Manajemen Universitas Tadulako}

Kecerdasan emosional mampu melatih kemampuan mahasiswa, yaitu kemampuan untuk mengelola perasaannya, kemampuan untuk memotivasi dirinya sendiri, kesanggupan mengendalikan dorongan dan mampu berempati dan bekerjasama dengan orang lain, Trisniwati dan Suryaningrum (2003). Hasil penelitian bahwa Kecerdasan Emosional memiliki pengaruh yang secara simultan terhadap Prestasi AkademikMahasiswa Manajemen Fakultas Ekonomi Universitas Tadulako.

Hasil penelitian ini sejalan dengan penelitian Sinar Embong Bulan (2011) yang menyatakan bahwa kecerdasanemosional berpengaruh positif terhadap terhadap IPK Mahasiswa Fakultas Ekonomi Universitas Hasanuddin. Hasil ini sesuai yang dikemukakan Goleman (2001:39), yang menyatakan bahwa Kecerdasan emosi adalah kemampuan memantau dan mengendalikan perasaan sendiri dan orang lain serta menggunakan perasaan-perasaan tersebut untuk memandu pikiran dan tindakan, sehingga kecerdasan emosi sangat diperlukan untuk sukses dalam belajar dan bekerja sehingga dapat menghasilkan prestasi yang baik.

\section{KESIMPULAN DAN SARAN}

\section{Kesimpulan}

Berdasarkan hasil dan pembahasan penelitian maka berikut beberapa kesimpulan yang menyangkut penelitian ini dengan judul"Pengaruh Kecerdasan Intelektual dan Kecerdasan Emosional Terhadap Prestasi Akademik Mahasiswa Manajemen Fakultas Ekonomi Universitas Tadulako", adalah sebagai berikut:

1. Kecerdasan Intelektual dan Kecerdasan Emosional secara simultan berpengaruh terhadap Prestasi Akademik mahasiswa Manajemen Fakultas Ekonomi Universitas Tadulako.

2. Kecerdasan Intelektual berpengaruh signifikan terhadap Prestasi Akademik mahasiswa Manajemen Fakultas Ekonomi Universitas Tadulako.

3. Kecerdasan Emosional berpengaruh signifikan terhadap Prestasi Akademik mahasiswa Manajemen Fakultas Ekonomi Universitas Tadulako.

4. Kecerdasan Emosional memiliki pengaruh yang dominan terhadap Prestasi Akademik mahasiswa Manajemen Fakultas Ekonomi Universitas Tadulako.

\section{Saran}

Adapun saran-saran berdasarkan kesimpulan di atas ataupun saran-saran lainnya yang dapat penulis berikan adalah:

1. Bagi mahasiswa dapat meningkatkan kecerdasan intelektual salah satunya dengan lebih giat belajar di kampus maupun di rumah, karena hasil penelitian telah terbukti bahwa kecerdasan intelektual merupakan salah satu faktor yang mempengaruhi meningkatnya prestasi akademik.

2. Kecerdasan emosional mahasiswa dapat ditingkatkan salah satunya dengan cara mengelola diri melalui berbagai kegiatan kemahasiswaan dikampus atau mengikuti kegiatan organisasi lainnya, karena hasil penelitian telah terbukti bahwa dalam meningkatkan prestasi akademik yang diperlukan bukan hanya kecerdasan intelektual tetapi kecerdasan emosional juga penting. Keseimbangan antara kecerdasan intelektual dan kecerdasan emosional sangat diperlukan agar mendapat prestasi akademik yang baik.

3. Bagi peneliti selanjutnya diharapkan untuk mencari atau menambahkan, variabel-variabel lain selain dua variabel di atas, karena masih banyak faktor-faktor lainnya yang mempengaruhi prestasi akademik mahasiswa yang tidak dibahas pada penelitian ini, agar 
hasil penelitiannya memberikan kontribusi yang lebih bermakna pada pihak-pihak yang berkepentingan.

\section{REFERENSI}

Bloom, Benjamin S. 1956. Taxonomy of Educational Objectives: The Classification of Educational Goals. London: David McKay Company, Inc.

Dwijayanti. 2009. Pengaruh Kecerdasan Emosional, Kecerdasan Intelektual, Kecerdasan Spiritual Dan Kecerdasan Sosial Terhadap Pemahaman Akuntansi. Skripsi.Universitas Pembangunan Nasional "VETERAN". Jakarta

Febri Sulistiya (2012). Pengaruh Tingkat Kecerdasan Intelektual dan Kecerdasan Emosional Terhadap Prestasi Belajar Pendidikan Jasmani, Olahraga dan Kesehatan Pada Siswa di SMP N 15 Yogyakarta. Skripsi Fakultas Ilmu Keolahragaan Universitas Negeri Yogyakarta.

Goleman, Daniel. 2001. Emotional Inteligences :Kecerdasan Emosional, Mengapa EL LebihPenting Daripada IQ. PT.Gramedia: Jakarta.

Goleman, Daniel, 2003, Kecerdasan Emosional, terj. T. Hermaya, Cet. XIII, Jakarta: Gramedia Pustaka Utama

Goleman, Daniel, 2007.Ekonomi Intelegensi. PT. Gramedia Pustaka utama,Jakarta

Husein, Umar. 2008. Metode Penelitian Untuk Skripsi dan Tesis Bisnis. Jakarta. PT Rajagrafindo Persada

Joseph, G, 1978, Interpreting Psychological Test Data, Vol.1, New York VNR

Kartono, 1995. Psikologi Umum. Bandung: Mandar maju

Kuncoro, Mudrajad. 2009. Metode Riset Untuk Bisnis dan Ekonomi. Jakarta : Erlangga

Maria. 2012. Kecerdasan Emosional dan Pencapaian Prestasi Akademik Mahasiswa Di Jurusan Akuntansi Politeknik Negeri Sriwijaya. Jurnal Media Wahana Ekonomika, Vol. 9, No. 3, Oktober $2012: 51-61$

Sinar Embong Bulan (2011). Analisis Pengaruh Kecerdasan Intelektual Dan Kecerdasan Emosional Terhadap IPK Mahasiswa Akuntansi Pada Fakultas Ekonomi Universitas Hasanuddin. Skripsi Fakultas Ekonomi Universitas Hasanuddin.

Slameto.1995.Belajar Dan Factor-faktor Yang Mempengaruhinya (Jakarta:Rinekacipta). Edisirevisi Sternberg, R. J. 2008. Psikologi kogitif. Yogyakarta: Pustaka Pelajar.

Sugiyono.2009. Metode Penelitian Kuantitatif dan Kualitatif. CV. Alfabeta :Bandung.

Sugiyono. 2013. Metode Penelitian Manajemen. Bandung :Alfabeta

Suryabrata, S. 1998. Metodologi Penelitian. Cetakan sebelas.Jakarta : PT Raja GrafindoPersada Trisnawati, Eka Indah dan Suryaningrum Sri. 2003. Pengaruh Kecerdasan Emosional Terhadap Tingkat Pemahaman Akuntansi. Simposium Nasional Akuntansi VI. Surabaya. 